\title{
Seeds of Carthamus Tinctorius Submitted to Hydration: Morphological Aspects and Emergence
}

\author{
Claudia Borgmann ${ }^{1}$, Luciene Kazue Tokura ${ }^{1}$, Bruna de Villa ${ }^{1}$, Deonir Secco ${ }^{1}$, Jair Antonio Cruz Siqueira ${ }^{1}$, \\ Pablo Chang ${ }^{1}$, Alessandra Mayumi Tokura Alovisi ${ }^{2}$, Lucas Iarrocheski Rotta ${ }^{1}$, Vinicius Miola ${ }^{3}$, \\ Leonardo Doreto da Silva ${ }^{3}$, João Vitor Zanella ${ }^{3} \&$ Milton Felipe Hurban Ramos dos Santos ${ }^{3}$ \\ ${ }^{1}$ Post-graduate Program in Engineering of Energy in Agriculture, State University of West Paraná, Cascavel, \\ Paraná, Brazil \\ 2 Post-graduation Program in Agronomy, Federal University of Grande Dourados, Dourados, Mato Grosso do \\ Sul, Brazil \\ ${ }^{3}$ Graduate Program in Agronomy, Assis Gurgacz Foundation University Center, Cascavel, Paraná, Brazil \\ Correspondence: Claudia Borgmann, Post-graduate Program in Engineering of Energy in Agriculture, State \\ University of West Paraná, Rua Universitária, 2069, Jardim Universitário, CEP: 85819-110, Cascavel, Paraná, \\ Brazil. Tel: 55-45-3-220-3151. E-mail: claudia.borg@hotmail.com
}

Received: May 22, 2019

doi:10.5539/jas.v11n16p38
Accepted: July 11, $2019 \quad$ Online Published: September 30, 2019

URL: https://doi.org/10.5539/jas.v11n16p38

\begin{abstract}
The present study aimed to evaluate the initial development of safflower genotypes (Carthamus tinctorius) after different periods of seed hydration. For the study two experiments were evaluated. At first, an experiment was performed with $0,24,48,72,168$ and 360 hours of seed hydration, and in the second moment, another with 0 , $12,24,36,48$ and 60 hours of hydration. The experimental design for the two experiments was completely randomized, with four replicates and six treatments. After 30 days of conduction of the experiments were analyzed the percentage of emergency, index of emergency speed, average time of emergency and average speed of emergency. The evaluated morphological characteristics were plant height, stem diameter, root length, fresh shoot and root mass and dry shoot mass. Hydration of seeds in considerable proportions positively influences the emergence and development of safflower plants. The highest performance in the emergence of plants, size, accumulation of fresh and dry shoot mass and fresh root mass was obtained by the IAPAR genotype, which stood out in relation to the other. The greatest emergencies were obtained with seeds with 36 hours of hydration, and the lowest emergence was found after 72 hours under hydration.
\end{abstract}

Keywords: hydration, safflower, seeds

\section{Introduction}

Looking for alternatives for the production of biodiesel, there is a plant little implemented in Brazil, known as safflower (Carthamus tinctorius L.). This plant has some very interesting characteristics, and the main one is to be adaptable in semi-arid climates, in such a way that it is highly capable of developing and producing satisfactorily in low water availability.

Because it has an enormous versatility, this plant has been used since antiquity, being used in the textile dyeing and in the culinary use (Abud et al., 2010). The safflower belonging to the family Asteraceae, is an annual herbaceous plant with possible origin in Asia and Africa.

In relation to safflower seeds, it has high quality oil, which can be used for human consumption and industrial use (Abud et al., 2010). The safflower seeds have high oil contents, ranging from 35 to $45 \%$. The oil has high contents of oleic acid (70-75\%) and linoleic acid (70-75\%) (Dantas et al., 2011; Zanetti et al., 2013).

Safflower develops in semi-arid climate (Omidi et al., 2012). However, for safflower as well as for other crops, the water deficit is one of the environmental factors that most affects the agricultural areas, culminating in the decrease of productivity. As a consequence, seed emergence can also be compromised and may delay and even inhibit the emergence of seeds. According to Dantas et al. (2011) emergence is the protrusion stage of one of the parts of the embryo that is associated with some sign of growth, such that this phase occurs with the absorption of water by the seeds, through a process of imbibition of the same. 
Taking this perspective into account, the pre-imbibing of seeds shows itself as an instrument for the production of diverse cultures. This is because, according to several studies, the prepared (pre-soaked) seeds emerged more quickly and uniformly compared to the others. In addition, seedlings had more vigor, harvests were earlier and larger (Costa et al., 2008; Bortolheiro, 2015; Lima, 2016).

It has been that through the imbibition process, the first stage of the emergency occurs with the absorption of water by the seeds. According to Rezende and Corrêa (2007), it is during this imbibition process that the water is diffused into the seed, providing an increase in its volume, which can occur both radially and axially in the grain. When the water diffuses in the interior it provides softening of the integument, culminating in the addition of the reserve tissues, increase in the stimuli to the digestion, together with the translocation and assimilation of the nutrients, thus providing the growth of the embryonic axis (Guimarães et al., 2008).

Guimarães et al. (2008) emphasize that the seed is the fertilized ovum of the plants, where it contains a new miniature plant. To prevent seed germination during drought, the seed enters a quiescence state, which enables resistance to adverse environmental conditions. The seed will only return to metabolic activity, when environmental conditions are favorable, especially when rehydrated (Guimarães et al., 2008).

Therefore, water can be considered the most determining factor in the seed emergence process. This is because, considering certain proportions, the greater the availability of water to the seeds, the faster the imbibition process (Carvalho \& Nakagawa, 1983). As safflower is a crop with a high energy potential, there is an interest in the maximum emergence potential of these seeds, so that germination occurs quickly and uniformly and the amount of water, nutrients and light be used with maximum efficiency.

Even though it has a high productive potential, safflower still has low expression in Brazil, which may be due to the lack of knowledge about the culture, mainly in relation to cultivation techniques. Thus, it is necessary to search a focus on the physiological aspects of safflower, in order to verify the response of this crop to climatic factors in different regions of the country. From this, the objective of the work was to evaluate two genotypes of Carthamus tinctorius L. on different periods of hydration of the seeds.

\section{Material and Methods}

The experiments were conducted in a greenhouse belonging to the State University of Western Paraná-UNIOESTE, in the municipality of Cascavel, Paraná. The greenhouse was constructed of polyethylene and the driving period was from May to June 2017. Two lots of Carthamus tinctorius L. seeds were used, with the genotypes IAPAR and IMA-2103. For the sowing of the genotypes there was a manual selection of the seeds uniform in terms of color and size.

For the installation of the experiment were used plastic cups of $500 \mathrm{ml}$, with dimension of $13.6 \mathrm{~cm}$ of height, 6.3 $\mathrm{cm}$ of base diameter and $8.5 \mathrm{~cm}$ of superior diameter. The seeds were seeded in plastic cups containing substrate, as described in Table 1.

Table 1. Chemical and physical characteristics of the substrate

\begin{tabular}{lllll}
\hline Electric conductivity & Density $\left(\mathrm{kg} \mathrm{m}^{-3}\right)$ & Hydrogen potential $(\mathrm{pH})$ & Maximum humidity $(\%)$ & Water retention capacity $(\%)$ \\
\hline $1.5 \pm 0.3$ & 480 & $6 \pm 0.5$ & 60 & 60 \\
\hline
\end{tabular}

The seed samples of each genotype were submitted to hydration, which consisted of leaving them submerged in distilled water, allocated in an environment protected from light and at room temperature.

In the first experiment the seed hydration consisted of $0,24,48,72,168$ and 360 hours, in order to verify if after 72 hours of hydration, the seedlings still had vigor in their emergence.

At 15 days after the first experiment, the second experiment was implanted with 0, 12, 24, 36, 48 and 60 hours of seed hydration.

The experiment was conducted in a completely randomized design, with four replicates and six treatments, totaling 24 experimental units for each experiment. For emergence of the seedlings, five seeds after the hydration periods were sown in each cup. The first experiment (EXP I) was seeded on 05/05/2017 and the second (EXP II), on $05 / 16 / 2017$. The seedlings were watered in the same amount of water every two days.

After 30 days of sowing, the data were submitted to emergency analysis, which evaluated the emergency percentage (EP), the emergency speed index (ESI), the mean time of emergency (MTE) and the mean velocity of emergence (MVE). 


$$
\begin{gathered}
\mathrm{EP}=\frac{\mathrm{SE}}{\mathrm{TS}} \times 100 \\
\mathrm{ESI}=\sum_{\mathrm{n}=1}^{\mathrm{n}} \frac{\mathrm{E}_{\mathrm{n}}}{\mathrm{N}_{\mathrm{n}}} \\
\mathrm{MTE}=\frac{\sum_{i=1}^{\mathrm{n}} \mathrm{g}_{\mathrm{n}} \mathrm{t}_{\mathrm{n}}}{\sum_{\mathrm{i}=1}^{\mathrm{n}} \mathrm{g}_{\mathrm{n}}} \\
\mathrm{MVE}=\frac{1}{\mathrm{t}}
\end{gathered}
$$

In relation to the morphological analysis, were evaluated the plant height (PH), root length (RL), stem diameter (SD), fresh shoot mass (FSM), shoot dry mass (SDM) and fresh root mass (FRM). A graduated ruler was used to determine $\mathrm{PH}$ and RL. A digital caliper $( \pm 0.01 \mathrm{~mm})$ was used for the determination of $\mathrm{SD}$, and a precision balance of the Marte brand, model AY220 ( $\pm 0.1 \mathrm{mg})$ was used for weighing. To obtain the SDM, a forced circulation oven of the brand Ethik, model 400 -TD $\left( \pm 0.1^{\circ} \mathrm{C}\right)$ was used.

Data were submitted to analysis of variance (ANOVA), using the F test and the means of the genotypes by means of the Tukey averages comparison test at $5 \%$ of significance. The software used for the analysis was R.

\section{Results and Discussion}

From the analysis of variance referring to the emergence of plants (Table 2), it was verified that the hours of hydration interfered significantly in their results $(\mathrm{p}>0.05)$. It is possible to identify that the emergency percentage (EP) decreased drastically as the seed hydration increased.

Similar results are found in the works of Costa et al. (2008) and Dantas et al. (2011), where the more hours of hydration the seeds had, the less the percentage the plants emerged. It is evident that the seeds after 72 hours of hydration, obtained less than $50 \%$ of the emergency percentage. That is, less than $50 \%$ of the plants emerged. This may have been influenced by the conditions of excess water, where the seed could absorb a lot of water, causing ruptures in its tissues (Rodrigues et al., 2006).

Regarding the genotype, the seeds of IMA-2103 presented a higher percentage of emergence. In the rest of the analyzed items (ESI, MTE and MVE), the results were considered equal $(p>0.05)$.

Table 2. Mean values of the emergency percentage (EP), emergency speed index (ESI), mean time of emergence (MTE), mean velocity of emergence (MVE), genotype and hours of hydration of Experiment I

\begin{tabular}{lllll}
\hline & EP (\%) & ESI (seeds/days) & MTE (days) & MES (days $\left.{ }^{-1}\right)$ \\
\hline ANOVA (Probability of the F test) & & & \\
Genotype (G) & $\mathrm{ns}$ & $\mathrm{Ns}$ & $\mathrm{ns}$ & $\mathrm{ns}$ \\
Hydration (H) & $* * *$ & $* * *$ & $* * *$ & $* * *$ \\
$\mathrm{G} \times \mathrm{H}$ & $\mathrm{ns}$ & $\mathrm{Ns}$ & $\mathrm{ns}$ & $\mathrm{ns}$ \\
$\mathrm{CV}(\%)$ & 23.16 & 30.5 & 45.75 & 52.48 \\
IAPAR & $50 \mathrm{~b}$ & $0.41 \mathrm{a}$ & $1.11 \mathrm{a}$ & $0.48 \mathrm{a}$ \\
IMA-2103 & $52.5 \mathrm{a}$ & $0.46 \mathrm{a}$ & $1.19 \mathrm{a}$ & $0.54 \mathrm{a}$ \\
\hline Test Tukey at $5 \%$ & & & & \\
$0 \mathrm{~h}$ & $85.0 \mathrm{a}$ & $0.69 \mathrm{a}$ & $1.5 \mathrm{a}$ & $0.7 \mathrm{a}$ \\
$24 \mathrm{~h}$ & $95.0 \mathrm{a}$ & $0.81 \mathrm{a}$ & $1.7 \mathrm{a}$ & $0.6 \mathrm{a}$ \\
$48 \mathrm{~h}$ & $77.5 \mathrm{a}$ & $0.75 \mathrm{a}$ & $1.6 \mathrm{a}$ & $0.6 \mathrm{a}$ \\
$72 \mathrm{~h}$ & $42.5 \mathrm{~b}$ & $0.32 \mathrm{~b}$ & $0.7 \mathrm{a}$ & $0.7 \mathrm{a}$ \\
$168 \mathrm{~h}$ & $7.50 \mathrm{c}$ & $0.07 \mathrm{c}$ & $0.4 \mathrm{~b}$ & $0.4 \mathrm{ab}$ \\
$360 \mathrm{~h}$ & $0.00 \mathrm{c}$ & $0.00 \mathrm{c}$ & $0.0 \mathrm{~b}$ & $0.0 \mathrm{~b}$ \\
\hline
\end{tabular}

Note. $\mathrm{CV}=$ Coefficient of variation; $\mathrm{ns}=$ not significant; $* * *=$ significant at $0.1 \%$. Equal letters in the column represent equal means by the Tukey test at $5 \%$ significance.

The highest emergency speed index (ESI) was presented in the treatment with 24 hours of seed hydration, presenting an ESI of 0.81, followed by treatment with 48 hours of hydration, with an ESI of 0.75 . By means of this, it can be understood that it is in the range of 24 to 48 hours of hydration that the seeds germinate more rapidly. In addition, it is worth mentioning that the highest coefficient of variation was identified for MVE, that is, it is for this question that the presented data were more dispersed. 
The highest mean time of emergence (MTE) was also identified in the 24 and 48 hours of hydration, with MTE of 1.7 and 1.6, respectively. In relation to the mean velocity of emergence (MVE), the lowest values were presented in the 24 and 48 hours of hydration, which may have been influenced by plants that had a later emergence.

In both genotypes, and in both treatments of hydration hours, the period after 72 hours did not present satisfactory results, evidencing that the most favorable periods to hydrate the seeds are between 0 and 48 hours. In Figure 1, the decrease of the emergence of the plants can be observed, as the period of hydration of the seeds increases. A study verified the viability of Brachiaria brizantha seeds by means of the tetrazolium test, where the number of hours of hydration combined with temperature were factors that influenced the emergence potential, concluding that the color of the tegument darkens as it increases, and the time of hydration (Novembre et al., 2006).

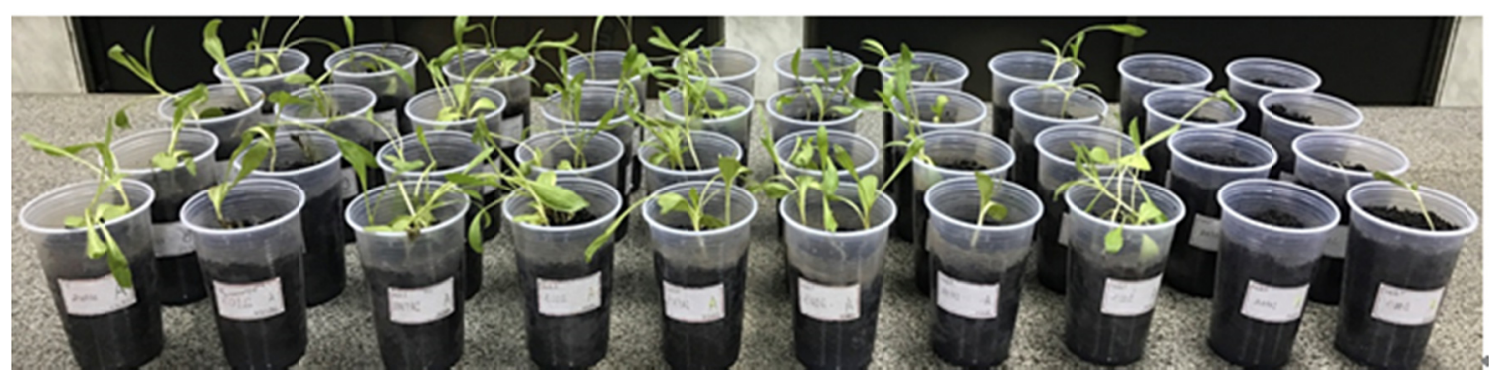

Figure 1. Emergence of safflower seedlings in plastic cups, from left to right, in the periods of $0 \mathrm{~h}, 24 \mathrm{~h}, 48 \mathrm{~h}, 72 \mathrm{~h}, 168 \mathrm{~h}$ and $360 \mathrm{~h}$ of hydration

Considering the need to perform one more experiment that needed to verify the best range of hours of hydration, a second experiment was performed with treatments of $0 \mathrm{~h}, 12 \mathrm{~h}, 24 \mathrm{~h}, 36 \mathrm{~h}, 48 \mathrm{~h}$ and $60 \mathrm{~h}$. Table 3 contains the values of the analysis of variance of the emergency percentage (EP), the emergency speed index (ESI), the mean time of emergence (MTE) and the mean velocity of emergence (MVE) of experiment II.

Table 3. Mean values of the emergency percentage (EP), emergency speed index (ESI), mean time of emergence (MTE), mean velocity of emergence (MVE), genotype and hours of hydration of Experiment II

\begin{tabular}{|c|c|c|c|c|}
\hline & $\mathrm{EP}(\%)$ & ESI (seeds/days) & MTE (days) & $\operatorname{MES}\left(\right.$ days $\left.^{-1}\right)$ \\
\hline \multicolumn{5}{|c|}{ ANOVA (Probability of the F test) } \\
\hline Genotype (G) & ns & Ns & ns & ns \\
\hline Hydration $(\mathrm{H})$ & $*$ & Ns & * & ns \\
\hline $\mathrm{G} \times \mathrm{H}$ & * & Ns & ns & ns \\
\hline $\mathrm{CV}(\%)$ & 28.68 & 31.67 & 27.83 & 32.82 \\
\hline IAPAR & $75.83 \mathrm{a}$ & $0.60 \mathrm{a}$ & $1.77 \mathrm{a}$ & $0.61 \mathrm{a}$ \\
\hline IMA-2103 & $74.16 \mathrm{a}$ & $0.61 \mathrm{a}$ & $1.76 \mathrm{a}$ & $0.55 \mathrm{a}$ \\
\hline \multicolumn{5}{|c|}{ Test Tukey at 5\% } \\
\hline $0 \mathrm{~h}$ & $80.0 \mathrm{a}$ & $0.58 \mathrm{~d}$ & $1.84 \mathrm{ab}$ & $0.58 \mathrm{ab}$ \\
\hline $12 \mathrm{~h}$ & $67.0 \mathrm{~b}$ & $0.54 \mathrm{c}$ & $1.86 \mathrm{ab}$ & $0.55 \mathrm{~b}$ \\
\hline $24 \mathrm{~h}$ & $80.0 \mathrm{a}$ & $0.62 \mathrm{~b}$ & $1.88 \mathrm{ab}$ & $0.55 \mathrm{~b}$ \\
\hline $36 \mathrm{~h}$ & $87.5 \mathrm{c}$ & $0.76 \mathrm{a}$ & $2.19 \mathrm{a}$ & $0.50 \mathrm{~b}$ \\
\hline $48 \mathrm{~h}$ & $67.5 \mathrm{~b}$ & $0.54 \mathrm{c}$ & $1.46 \mathrm{ab}$ & $0.73 \mathrm{a}$ \\
\hline $60 \mathrm{~h}$ & $67.5 \mathrm{~b}$ & $0.58 \mathrm{~d}$ & $1.39 \mathrm{~b}$ & $0.56 \mathrm{~b}$ \\
\hline
\end{tabular}

Note. $\mathrm{CV}=$ Coefficient of variation; $\mathrm{ns}=$ not significant; $*=$ significant at $5 \%$. Equal letters in the column represent equal means by the Tukey test at $5 \%$ significance. 
Regarding the emergency potential (EP), the treatment that obtained the highest result was the 36 hours of hydration. This period also presented the highest emergency speed index (ESI), mean time of emergency (MTE) and mean velocity of emergence (MVE).

The genotypes, IAPAR and IMA-2103 presented similar developments in all treatments (EP, ESI, MTE and MES), denoting that they did not interfere significantly in their results $(p>0.05)$.

For the treatment of 12 hours of hydration, some error could have occurred during data collection. This is justified, because the 0 hours of hydration obtained values close to 24 hours of hydration, so it would not be in the 12 hours that it would have a considerably lower value.

In general, seed hydration at a suitable percentage is the determining factor for increased emergence. It should be noted that the permanence of seeds in water varies with the species, as it collaborates to make the seed coat more permeable to water. In this sense, at 36 hours of seed hydration, it can be considered the ideal for a higher performance of safflower culture.

In addition to the emergency analyzes, morphometric analyzes were also performed (Tables 4 and 5) for both experiments.

Table 4. Mean values of interaction between genotypes and hydration hours for plant height ( $\mathrm{PH})$ root length (RL), stem diameter (SD) fresh shoot mass (FSM), dry shoot mass (DSM) and mass dry root (MDR) from Experiment I

\begin{tabular}{|c|c|c|c|c|c|c|}
\hline Treatment & $\mathrm{PH}(\mathrm{cm})$ & $\mathrm{RL}(\mathrm{cm})$ & $\mathrm{SD}(\mathrm{mm})$ & FSM (g) & DSM (g) & MDR (g) \\
\hline \multicolumn{7}{|l|}{ Genotype } \\
\hline IAPAR & $15.3 \mathrm{a}$ & $10.47 \mathrm{a}$ & $2.18 \mathrm{a}$ & $0.71 \mathrm{a}$ & $0.039 \mathrm{a}$ & $0.12 \mathrm{a}$ \\
\hline IMA-2103 & $13.5 \mathrm{a}$ & $8.92 \mathrm{a}$ & $2.08 \mathrm{a}$ & $0.55 \mathrm{~b}$ & $0.032 \mathrm{~b}$ & $0.12 \mathrm{a}$ \\
\hline \multicolumn{7}{|l|}{ Hydration } \\
\hline $0 \mathrm{~h}$ & $16.3 \mathrm{a}$ & $10.83 \mathrm{a}$ & $2.14 \mathrm{a}$ & $0.63 \mathrm{a}$ & $0.039 \mathrm{a}$ & $0.12 \mathrm{a}$ \\
\hline $24 \mathrm{~h}$ & $14.2 \mathrm{a}$ & $9.55 \mathrm{~b}$ & $2.08 \mathrm{a}$ & $0.57 \mathrm{a}$ & $0.035 \mathrm{a}$ & $0.11 \mathrm{a}$ \\
\hline $48 \mathrm{~h}$ & $14.1 \mathrm{a}$ & $9.17 \mathrm{~b}$ & $2.20 \mathrm{a}$ & $0.72 \mathrm{a}$ & $0.037 \mathrm{a}$ & $0.17 \mathrm{a}$ \\
\hline $72 \mathrm{~h}$ & $13.9 \mathrm{a}$ & $8.84 \mathrm{~b}$ & $2.06 \mathrm{a}$ & $0.62 \mathrm{a}$ & $0.033 \mathrm{a}$ & $0.08 \mathrm{a}$ \\
\hline $168 \mathrm{~h}$ & $9.75 \mathrm{~b}$ & $15.00 \mathrm{~b}$ & $2.35 \mathrm{a}$ & $0.32 \mathrm{~b}$ & $0.023 \mathrm{~b}$ & $0.08 \mathrm{a}$ \\
\hline $360 \mathrm{~h}$ & $0.00 \mathrm{~b}$ & $0.00 \mathrm{c}$ & $0.00 \mathrm{~b}$ & $0.00 \mathrm{c}$ & $0.000 \mathrm{c}$ & $0.00 \mathrm{~b}$ \\
\hline \multicolumn{7}{|c|}{ ANOVA (Probability of the F test) } \\
\hline Genotype (G) & $\cdot$ & . & . & $* *$ & $* *$ & ns \\
\hline Hydration (I) & . & . & ns & $\cdot$ & $\cdot$ & ns \\
\hline $\mathrm{G} \times \mathrm{I}$ & ns & ns & $*$ & ns & ns & ns \\
\hline $\mathrm{CV}(\%)$ & 13.1 & 27.61 & 9.08 & 29.01 & 22.30 & 101.14 \\
\hline
\end{tabular}

Note. $\mathrm{CV}=$ Coefficient of variation; $\mathrm{ns}=$ not significant; $\cdot=$ significant at $10 \% ; *=$ significant at $5 \%$; $* *$ significant at $1 \%$. Equal letters in the column represent equal means by the Tukey test at $5 \%$ significance. 
Table 5. Mean values of interaction between genotypes and hydration hours for plant height (PH) root length (RL), stem diameter (SD) fresh shoot mass (FSM), dry shoot mass (DSM) and mass dry root (MDR) from Experiment II

\begin{tabular}{|c|c|c|c|c|c|c|}
\hline Treatment & $\mathrm{PH}(\mathrm{cm})$ & $\mathrm{RL}(\mathrm{cm})$ & $\mathrm{SD}(\mathrm{mm})$ & FSM (g) & $\operatorname{DSM}(\mathrm{g})$ & $\operatorname{MDR}(\mathrm{g})$ \\
\hline \multicolumn{7}{|l|}{ Genotype } \\
\hline IAPAR & $38.85 \mathrm{a}$ & $20.24 \mathrm{a}$ & $2.52 \mathrm{a}$ & $1.31 \mathrm{a}$ & $0.076 \mathrm{a}$ & $0.27 \mathrm{a}$ \\
\hline IMA-2103 & $17.97 \mathrm{~b}$ & $15.05 \mathrm{~b}$ & $2.06 \mathrm{~b}$ & $1.02 \mathrm{~b}$ & $0.064 \mathrm{~b}$ & $0.16 \mathrm{~b}$ \\
\hline \multicolumn{7}{|l|}{ Hydration } \\
\hline $0 \mathrm{~h}$ & $31.85 \mathrm{a}$ & $18.80 \mathrm{a}$ & $2.41 \mathrm{a}$ & $1.56 \mathrm{a}$ & $0.096 \mathrm{a}$ & $0.306 \mathrm{a}$ \\
\hline $12 \mathrm{~h}$ & $24.29 \mathrm{~b}$ & $13.95 \mathrm{~b}$ & $1.99 \mathrm{~b}$ & $0.66 \mathrm{~d}$ & $0.048 \mathrm{c}$ & $0.081 \mathrm{~b}$ \\
\hline $24 \mathrm{~h}$ & $24.79 \mathrm{~b}$ & $17.24 \mathrm{ab}$ & $2.04 \mathrm{~b}$ & $0.79 \mathrm{~cd}$ & $0.051 \mathrm{c}$ & $0.212 \mathrm{ab}$ \\
\hline $36 \mathrm{~h}$ & $29.61 \mathrm{a}$ & $18.48 \mathrm{a}$ & $2.51 \mathrm{a}$ & $1.40 \mathrm{ab}$ & $0.078 \mathrm{ab}$ & $0.211 \mathrm{ab}$ \\
\hline $48 \mathrm{~h}$ & $31.65 \mathrm{a}$ & $19.77 \mathrm{a}$ & $2.49 \mathrm{a}$ & $1.41 \mathrm{ab}$ & $0.080 \mathrm{ab}$ & $0.224 \mathrm{ab}$ \\
\hline $60 \mathrm{~h}$ & $28.27 \mathrm{ab}$ & $17.65 \mathrm{ab}$ & $2.32 \mathrm{a}$ & $1.17 \mathrm{bc}$ & $0.068 \mathrm{bc}$ & $0.264 \mathrm{a}$ \\
\hline \multicolumn{7}{|c|}{ ANOVA (Probability of the F test) } \\
\hline Genotype (G) & $* * *$ & $* * *$ & $* * *$ & $* * *$ & $* *$ & $* *$ \\
\hline Hydration (I) & $* * *$ & $* * *$ & $* * *$ & $* * *$ & $* * *$ & $* *$ \\
\hline $\mathrm{G} \times \mathrm{I}$ & ns & $\cdot$ & $*$ & ns & $\cdot$ & ns \\
\hline $\mathrm{CV}(\%)$ & 12.88 & 18.14 & 8.27 & 27.69 & 23.91 & 64.04 \\
\hline
\end{tabular}

Note. $\mathrm{CV}=$ Coefficient of variation; $\mathrm{ns}=$ not significant; $\cdot=$ significant at $10 \% ; *=$ significant at $5 \%$; $* *$ significant at $1 \% ; * * *$ significant at $0.1 \%$. Equal letters in the column represent equal means by the Tukey test at $5 \%$ significance.

In the first experiment (Table 4), the IAPAR genotype presented higher averages in all the analyzed questions, however it was for the fresh and dry mass of the aerial part that the Tukey's test ( $p>0.05)$ denoted a significant difference between the data.

With increasing hours of hydration, some morphological aspects obtained a decrease of its characteristics. This is evident for plant height, root length, fresh and dry shoot mass, and fresh root mass. In relation to root formation, the hours of hydration allowed a decrease in the root volume, mainly of the secondary roots, with only the main root remaining, which is pivotant root, as shown in Figures 2 and 3.

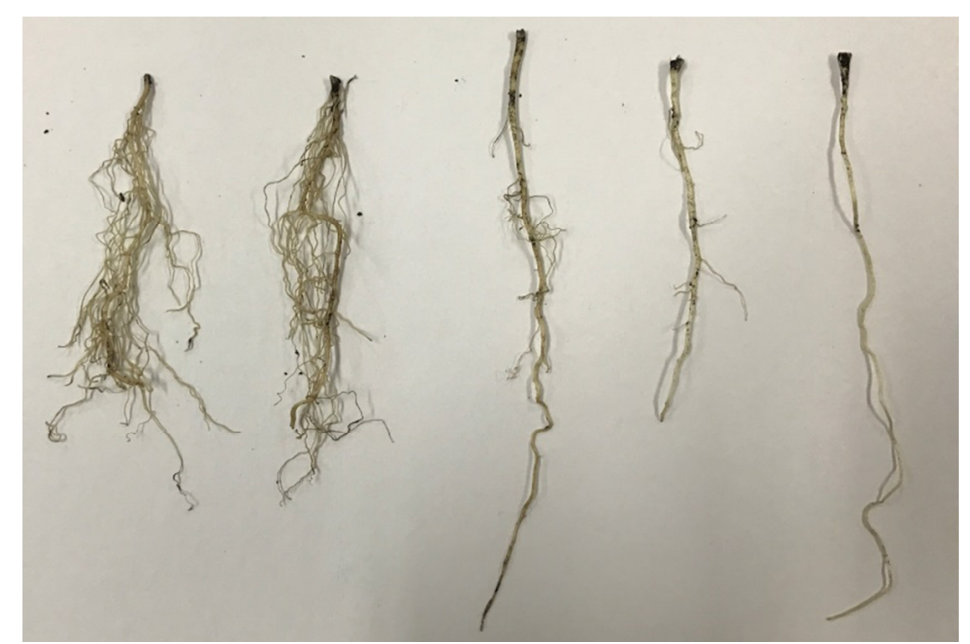

Figure 2. Safflower roots of the genotype IMA-2103, one root per treatment, from left to right, $0 \mathrm{~h}, 24 \mathrm{~h}, 48 \mathrm{~h}, 72 \mathrm{~h}$ and $168 \mathrm{~h}$ of hydration 


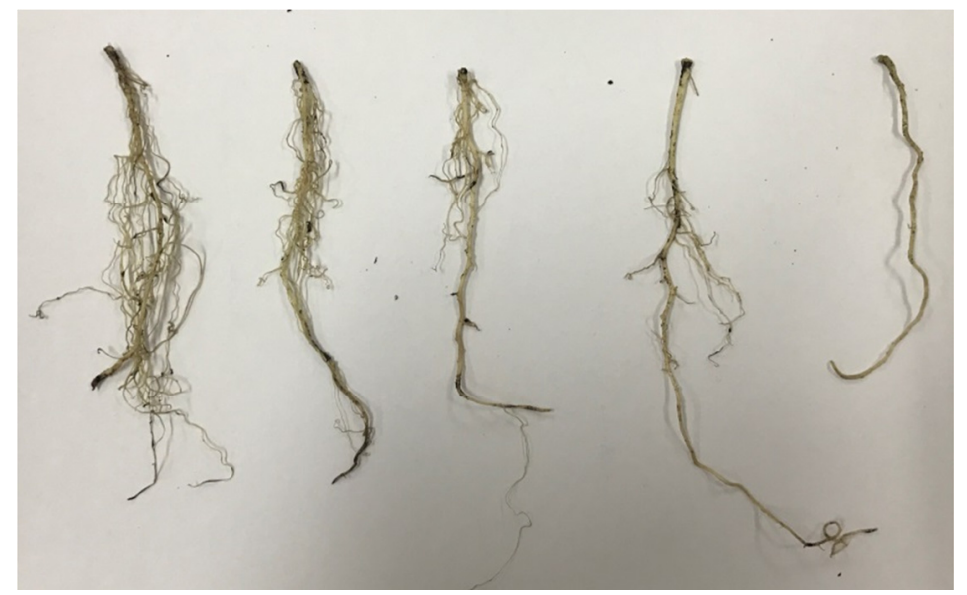

Figure 3. Safflower roots of the genotype IAPAR, one root per treatment, from left to right, $0 \mathrm{~h}, 24 \mathrm{~h}, 48 \mathrm{~h}, 72 \mathrm{~h}$ and $168 \mathrm{~h}$ of hydration

It is observed a greater adaptation of the seed hydration of the IAPAR genotype, evidencing the superiority of this in all treatments, by the significant difference $(p>0.05)$.

The highest mean height of plants was found in the control, where the seeds did not receive hydration. However, according to the Tukey test at 5\% significance, $0 \mathrm{~h}, 36 \mathrm{~h}$ and $48 \mathrm{~h}$ showed no differences. Similar results were found for root length. Results that follow this idea are presented in the fresh root mass, which presented the highest mean in the control, however, according to the Tukey test at 5\% significance, the treatments with $0 \mathrm{~h}, 24$ $\mathrm{h}, 36 \mathrm{~h}, 48 \mathrm{~h}$ and $60 \mathrm{~h}$ are equals.

In relation to the fresh and dry mass of the aerial part, the lowest averages found were of treatments of $12 \mathrm{~h}$ and $24 \mathrm{~h}$ of hydration. Denoting, probably, that the little hydration of seeds did not present favorable results as the others.

In general, comparing the first experiment with the second one, it was verified in the second, the plants were more vigorous and healthy, which can be a consequence of the periods chosen for hydration of the seeds, as well as of the climate, which was different for both times of planting.

\section{Conclusion}

The IAPAR genotype responded favorably to seed hydration in the two experiments, due to higher emergence, plant height, fresh and dry mass accumulation, and root mass. The period of 36 hours of hydration was considered ideal, presenting greater emergency potentials. After the 72 hours of seed hydration, the emergence was lower than without hydration, not being indicated the hydration of the seeds after this period.

\section{References}

Abud, H. F., Gonçalves, N. R., Reis, R. D. G. E., Gallão, M. I., \& Innecco, R. (2010). Morfologia de sementes e plântulas de cártamos. Revista Ciência Agronômica, 41(2), 259-265. https://doi.org/10.1590/S1806-6690 2010000200013

Bortolheiro, F. P. A. P. (2015). Caracterização de linhagens de cártamo (Carthamus tinctorius L.) em condições de deficiência hídrica e reidratação (Dissertação Mestrado, Universidade Estadual Paulista, Faculdade de Ciências Agronômicas, Botucatu).

Carvalho, N. M., \& Nakagawa, J. (1983). Sementes: Ciência, tecnologia e produção (p. 588). Jaboticabal: FUNEP.

Costa, C. J., Villela, F. A., Bertoncello, M. R., Tillmann, M. A. A., \& Menezes, N. L. (2008). Pré-hidratação de sementes de ervilha e sua interferência na avaliação do potencial fisiológico. Revista Brasileira de Sementes, 30(1), 198-207. https://doi.org/10.1590/S0101-31222008000100025

Dantas, C. V. S., Silva, I. B., Pereira, G. M., Maia, J. M., Lima, J. P. M. S., \& Macedo, C. E. S. (2011). Influência da sanidade e déficit hídrico na germinação de sementes de Carthamus tinctorius L. Revista Brasileira de Sementes, 33(3), 574-582. https://doi.org/10.1590/S0101-31222011000300020 
Guimarães, M. A., Dias, D. C. F. S., \& Loureiro, M. E. (2008). Hidratação de sementes. Revista Trópica-Ciências Agrárias e Biológicas, 2(1), 31-39.

Lima, J. G. S. (2016). Influência dos estresses hídrico e salino nos sistemas antioxidante e lipídico durante a transição semente-plântula em cártamo (Dissertação de Mestrado, Brasil).

Novembre, A. D. L. C., Chamma, H. M. C. P., \& Gomes, R. B. R. (2006). Viabilidade das sementes de braquiária pelo teste de tetrazólio. Revista Brasileira de Sementes, 28(2), 147-151. https://doi.org/10.1590/ S0101-31222006000200020

Omidi, A. H., Khazaei, H., Monneveux, P., \& Stoddard, F. L. (2012). Effect of cultivar and water regime on yield and yield components in safflower (Carthamus tinctorius L.). Turkish Journal of Field Crops, 17(1), $10-15$.

Resende, O., \& Corrêa, P. C. (2007). Modelagem matemática do processo de hidratação de sementes de feijão. Acta Scientiarum. Agronomy, 29(3), 373-378. https://doi.org/10.4025/actasciagron.v29i3.387

Rodrigues, M. B. C., Villela, F. A., Tillmann, M. A. A., \& Carvalho, R. (2006). Pré-hidratação em sementes de soja e eficiência do teste de condutividade elétrica. Revista Brasileira de Sementes, 28(2), 168-181. https://doi.org/10.1590/S0101-31222006000200023

Zanetti, F., Monti, A., \& Berti, M. T. (2013). Challenges and opportunities for new industrial oilseed crops in EU-27: A review. Industrial Crops \& Products, 50, 580-595. https://doi.org/10.1016/j.indcrop.2013.08.030

\section{Copyrights}

Copyright for this article is retained by the author(s), with first publication rights granted to the journal.

This is an open-access article distributed under the terms and conditions of the Creative Commons Attribution license (http://creativecommons.org/licenses/by/4.0/). 